\title{
Effect of curcumin on lung injury induced by skeletal muscle ischemia/reperfusion in rats
}

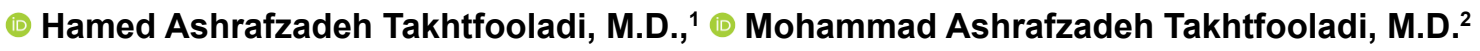

${ }^{1}$ Department of Pathobiology, Science and Research Branch, Islamic Azad University, Tehran-Iran

${ }^{2}$ Young Researchers and Elites Club, Science and Research Branch, Islamic Azad University, Tehran-Iran

\begin{abstract}
BACKGROUND: The aim of the present study was to investigate the effects of curcumin on lung damage following ischemia/reperfusion (I/R) injury after hind limb ligation.

METHODS: Forty Wistar rats were divided into four groups: sham (GI), I/R (G2), curcumin plus sham (G3), and curcumin plus I/R (G4). Curcumin was administered $(200 \mathrm{mg} / \mathrm{kg}$ ) daily for 2 weeks before the study. I/R was induced by placement of rubber tourniquets at the greater trochanters for $2 \mathrm{~h}$, followed by reperfusion for $4 \mathrm{~h}$.

RESULTS: Curcumin pretreatment had significantly lower level of malondialdehydes and higher level of superoxide dismutase in the lung tissues $(p<0.05)$ than the I/R group. Glutathione peroxidase activity was not significantly different among the groups $(p>0.05)$. I/R caused severe histopathological injury $(p<0.05)$, including inflammatory cell infiltration and intra-alveolar hemorrhage.
\end{abstract}

CONCLUSION: These results suggest that curcumin pretreatment has protective effects against lung injury induced by muscle $\mathrm{I} / \mathrm{R}$. Keywords: Curcumin; ischemia/reperfusion; lung; skeletal muscle.

\section{INTRODUCTION}

Ischemia/reperfusion (I/R) injury of the skeletal muscles is inevitable in various clinical conditions. This type of injury can occur from long surgical interventions on the extremities. It can damage parenchymal and endothelial cells, induce granulocyte and macrophage reactions, and trigger humoral factors (e.g., coagulation factors and oxygen free radicals). ${ }^{[1,2]}$

It is possible for $I / R$ injuries to extend further than the ischemic region and cause damage to remote organs. One of the major causes of morbidity and mortality is lung injury following I/R damage to the extremities according to the literature. Increased microvascular permeability, as well as pulmonary edema, characterizes this type of injury. ${ }^{[3]}$

Inflammatory mediators, particularly oxygen free radicals and neutrophils, contribute to the development of lung injuries associated with I/R damage according to previous studies. ${ }^{[4-7]}$
Efforts have been made to develop novel treatment methods in order to prevent or limit damage to remote organs. Accordingly, various studies have used different pharmacological agents for this purpose. ${ }^{[8-10]}$ Curcumin with anticarcinogenic and anti-inflammatory effects is recognized as a potential stimulator of heat shock protein expression induced by stress. ${ }^{\left[{ }^{\prime I}\right]}$ It can improve I/R damages in the kidneys, myocardium, and nervous tissues based on recent studies. ${ }^{[12-16]}$ However, to our knowledge, no studies have examined the effects of this compound on the lungs following I/R damage to the muscles. Accordingly, we examined the effectiveness of curcumin against muscle I/R damage. Histological and biochemical analyses were performed in order to assess its protective effects.

\section{MATERIALS AND METHODS}

The Animal Experiments Committee of Islamic Azad University approved the study protocol (2015-A2/0I7-4). The Pas-

Cite this article as: Takhtfooladi HA, Takhtfooladi MA. Effect of curcumin on lung injury induced by skeletal muscle ischemia/reperfusion in rats. Ulus Travma Acil Cerrahi Derg 2019;25:7-11.

Address for correspondence: Mohammad Ashrafzadeh Takhtfooladi, M.D.

Science and Research Branch, Islamic Azad University, Tehran, Iran.

Tel: 00989/32004875 E-mail:dr_ashrafzadeh@yahoo.com

Ulus Travma Acil Cerrahi Derg 2019;25(I):7-II DOI: 10.5505/tjtes.2018.83616 Submitted: 14.08.2017 Accepted: 07.03.2018 Online: 30.12.2018

Copyright 2019 Turkish Association of Trauma and Emergency Surgery 
Table I. Histological grading according to Koksel's protocol

$\begin{array}{ll}\text { Grade } 0 & \text { Normal appearance } \\ \text { Grade I } & \text { Mild-moderate interstitial congestion and neutrophil } \\ & \text { leukocyte infiltration }\end{array}$

Grade 2 Perivascular edema formation, partial destruction of pulmonary architecture, and moderate neutrophil leukocyte infiltration

Grade 3 Complete destruction of the pulmonary architecture and dense neutrophil leukocyte

teur Institute of Iran supplied 40 adult male Wistar rats. The mean weight of the rats was $230 \pm 20 \mathrm{~g}$. The rats were kept at a temperature of $22{ }^{\circ} \mathrm{C} \pm 2{ }^{\circ} \mathrm{C}$ (relative humidity, $45 \% \pm 5 \%$ and I2: $12 \mathrm{~h}$ light/dark cycle) with access to food and water.

The rats were randomly allocated to four groups ( 10 rats each): sham (GI), I/R (G2), curcumin plus sham (G3), and curcumin plus I/R (G4). Curcumin (Sigma Co., MO, USA) was administered via oral gavage at a dose of $200 \mathrm{mg} / \mathrm{kg} /$ day. It was dissolved in corn oil (C8267; Sigma Co.) for 2 weeks before the study.

Ketamine $(50 \mathrm{mg} / \mathrm{kg})$ and xylazine $(5 \mathrm{mg} / \mathrm{kg})$ were administered to induce anesthesia. Ischemia was induced by placing orthodontic rubber bands at both hip joints for 2 h. Body temperature was kept constant using a warming pad. After reperfusion for $4 \mathrm{~h}$, the rats were euthanized, and the lungs were removed. Then, the left lungs were placed in a $10 \%$ formalin solution and prepared for histopathological examination via light microscopy.

The supernatants of the right lung homogenates were prepared as described by Yildirim et al. ${ }^{[17]}$ The malondialdehyde (MDA) level was determined via thiobarbituric acid reactions based on the study by Yagi. ${ }^{[18]}$ In addition, superoxide dismutase (SOD) activity was analyzed spectrophotometrically $(560 \mathrm{~nm})$ by determining the capacity to inhibit photochem- ical nitroblue tetrazolium reduction based on the method proposed by Winterbourn et al. ${ }^{[19]}$ Moreover, glutathione peroxidase (GSH-Px) activities were spectrophotometrically (340 nm) determined using the method proposed by Paglia and Valentine. ${ }^{[20]}$

Standard methods were used to process the left lung specimens. Cross-sectional cuts ( $5 \mu \mathrm{m}$ in thickness) were made in the middle of the lungs. The hematoxylin and eosin method was applied for staining the slides. Lung injuries were examined in accordance with Koksel's protocol ${ }^{[2 I]}$ (Table I).

Data were analyzed using SPSS version 18.0 (SPSS Inc., Chicago, IL, USA). The Mann-Whitney $U$ test was used for non-parametric analyses of biochemical variables. The ANOVA and Tukey's tests were used for comparison of data. A $P$ value $<0.05$ was considered significant.

\section{RESULTS}

No significant lung histological changes were found in the GI and G3 groups based on light microscopy ( $p>0.05)$. After reperfusion for $4 \mathrm{~h}$, extensive infiltration of inflammatory cells and intra-alveolar hemorrhage were reported in the G2 group (Figs. la, b). At this time, lung damage was less in the G4 group (Fig. Ic). Therefore, lung injuries caused by muscle I/R were more severe in the G2 group than in the G4 group ( $p<0.05$; Fig. 2).

The G2 group showed a significantly higher MDA level than others ( $p<0.05 ; \mathrm{Fig} .3$ ). On the other hand, SOD activity was significantly lower in the G2 group ( $p<0.05$; Fig. 4). Based on the findings, the groups were significantly different in terms of GSH-Px activity ( $p>0.05$; Fig. 5). No significant difference was found among the GI, G3, and G4 groups according to the biochemical results $(p>0.05)$.

\section{DISCUSSION}

I/R injury is characterized by a sequence of events, resulting in damage to the cells and organ dysfunction. ${ }^{[22]}$ Various
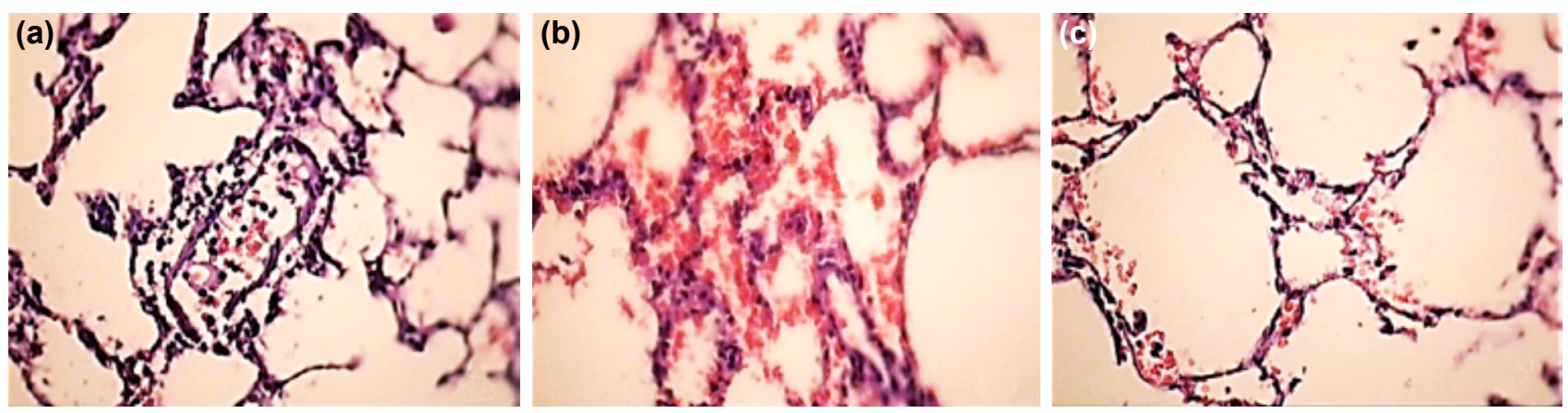

Figure 1. ( $a$ and b) Light photomicrographs of the lung tissues from rats subjected to ischemia/reperfusion without curcumin pretreatment (G2). (a) Inflammatory cell infiltration. (b) Intra-alveolar hemorrhage. (c) Light photomicrograph of the lung tissues from rats pretreated with $200 \mathrm{mg} / \mathrm{kg} /$ day curcumin for 2 weeks before ischemia/reperfusion (G4), showing nearly normal alveolar architecture and less of the slight neutrophil infiltration; (haematoxylin-eosin, original magnification $\times 400$ ). 


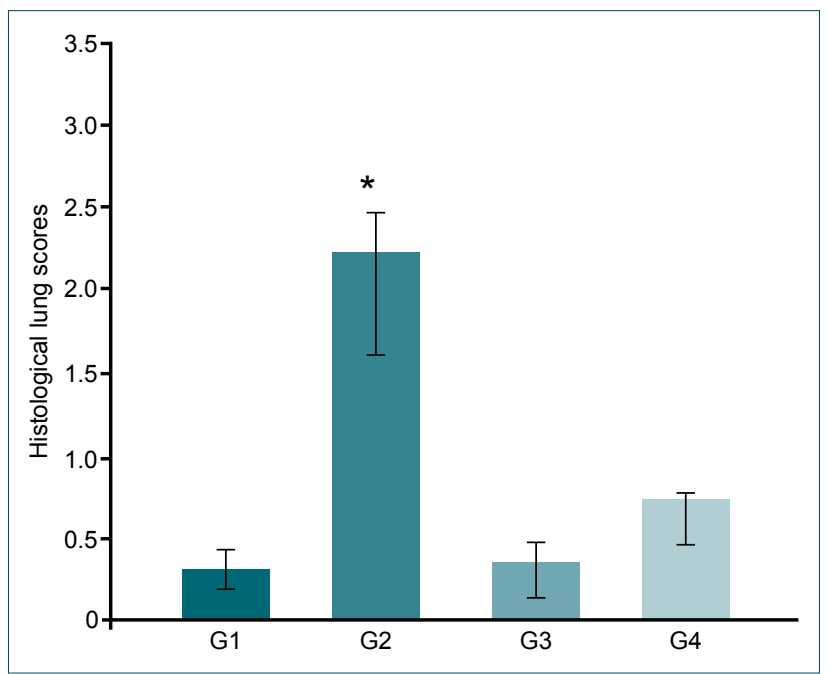

Figure 2. Histological lung injury scores in the experimental groups. Sham (G1), ischemia/reperfusion (G2), curcumin plus sham (G3), and curcumin plus $\mathrm{I} / \mathrm{R}(\mathrm{G} 4)$. ${ }^{*} \mathrm{P}<0.05$.

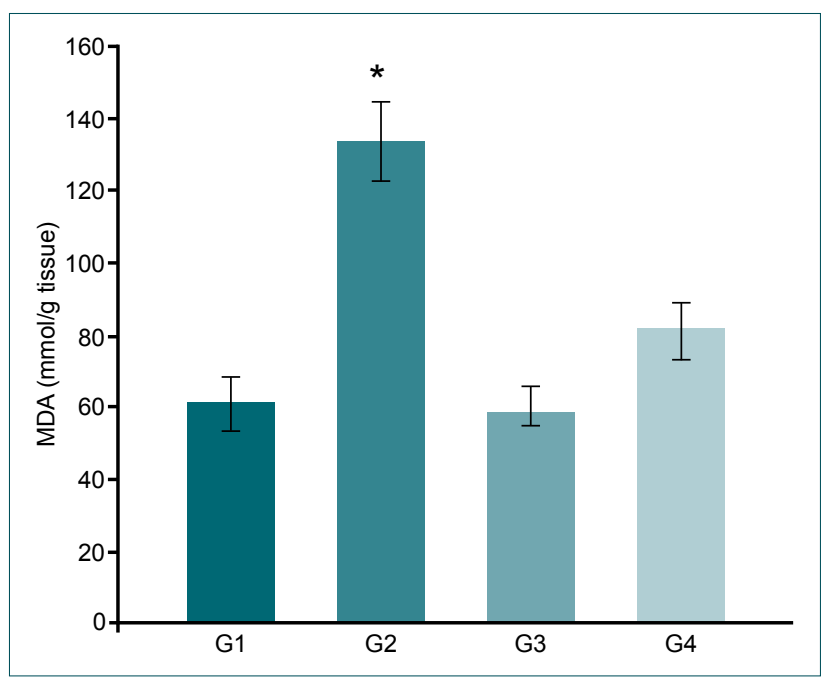

Figure 3. The graph shows the malondialdehyde (MDA) level of different groups. Each group contains mean $\pm S D$ of ten animals. Sham (G1), ischemia/reperfusion (G2), curcumin plus sham (G3), and curcumin plus $\mathrm{I} / \mathrm{R}(\mathrm{G} 4)$. ${ }^{*} \mathrm{P}<0.05$.

studies have been performed on the role and importance of neutrophils in $\mathrm{I} / \mathrm{R}$ damage. ${ }^{[23,24]}$ Based on speculations, one of the major pathological dysfunctions in lung injury is endothelial cell damage, resulting from neutrophil activation, which can lead to inflammatory cytokine production and release of oxygen free radicals. ${ }^{[25]}$

Curcumin is regarded as an effective compound in eliminating $\mathrm{I} / \mathrm{R}$ damage to different organs. ${ }^{[26,27]}$ It can be effective against $\mathrm{I} / \mathrm{R}$ injuries of the muscles according to a recent study by Avci et al. ${ }^{[28]}$ This compound has been shown to be effective in human and animal models of I/R injury. Moreover, it can be useful in the treatment of diseases, such as cancer, diabetes, cardiovascular disorders, and arthritis. ${ }^{[2]]}$

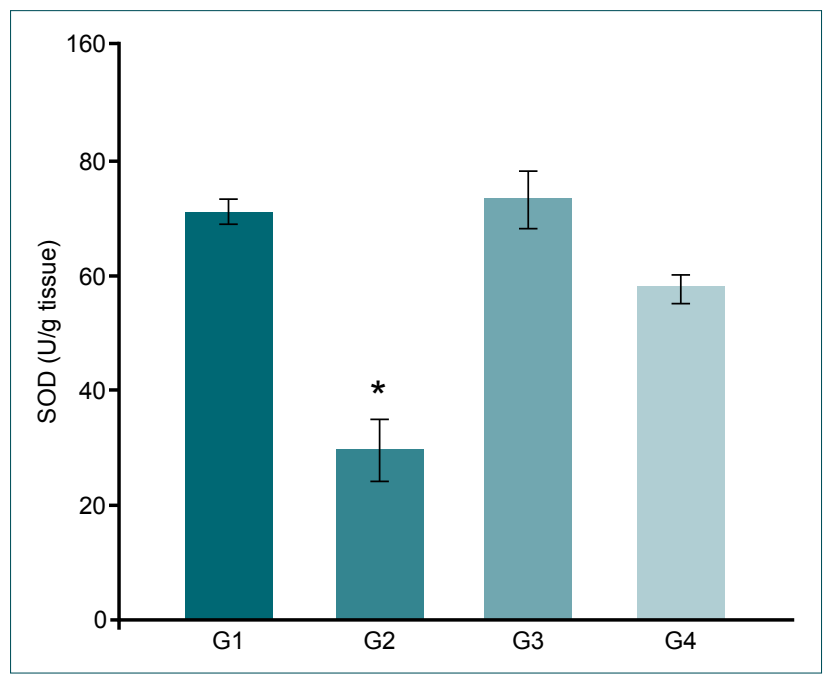

Figure 4. The graph shows the superoxide dismutase (SOD) activity of different groups. Each group contains mean $\pm S D$ of seven animals. Sham (G1), ischemia/reperfusion (G2), curcumin plus sham (G3), and curcumin plus $\mathrm{I} / \mathrm{R}(\mathrm{G} 4) .{ }^{*} \mathrm{P}<0.05$.

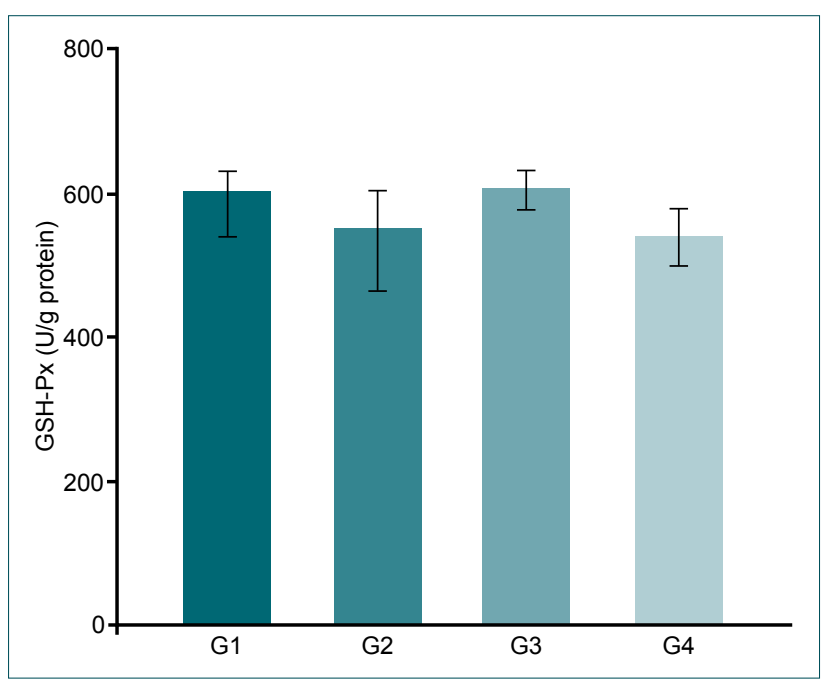

Figure 5. The graph shows the glutathione peroxidase (GSH$P x)$ activity of different groups. Each group contains mean $\pm S D$ of seven animals. Sham (G1), ischemia/reperfusion (G2), curcumin plus sham (G3), and curcumin plus I/R (G4). There was not significantly different among the groups $(p>0.05)$.

The protective effects of curcumin are attributed to improved oxidative stress and inhibitory activities of protein kinases, adhesion molecules, inflammatory transcription factors, and inflammation. ${ }^{[26,27,29]}$ Some studies have revealed its potential for scavenging free radicals to prevent lipid peroxidation and increase the level of intracellular antioxidants. ${ }^{[30-34]}$

In the present study, light microscopy indicated the disruption of alveolar architecture, as well as neutrophil infiltration in histopathological sections in the G2 group. However, sections from the group receiving curcumin demonstrated decreased histological damage. It appears that curcumin can significantly attenuate leukocyte recruitment in the lung tissues 
after muscle I/R, as demonstrated by the significantly higher number of neutrophils and greater histological damage to the lungs in the $\mathrm{G} 2$ group than in others.

One of the important causes of lung injury is lipid peroxidation, triggered by oxygen free radicals. ${ }^{[35]}$ In our study, lung injury after muscle I/R was associated with high MDA levels in the lung tissues (a proper marker of lipid peroxidation). ${ }^{[36]}$ Nevertheless, curcumin could significantly decrease the MDA level. This finding is in line with previous studies, representing curcumin as an inhibitor of lipid peroxidation. ${ }^{[30]}$

Additionally, evidence has revealed the antioxidant activities of curcumin (especially inhibition of lipid peroxidation). ${ }^{[30]}$ In the current study, the protective effects of curcumin on the cells against lipid peroxidation might be attributed to its direct antioxidant and anti-inflammatory activities.

Based on the present findings, pretreatment with curcumin can reduce lung injuries resulting from muscle I/R. Inhibition of neutrophil aggregation, as well as oxidative damage in the injured lung, might be the underlying mechanisms. Further research is required to confirm the clinical effectiveness of this compound.

\section{Funding: None.}

Ethical approval: All applicable international, national, and/or institutional guidelines for the care and use of animals were followed.

\section{Conflict of interest: None declared.}

\section{REFERENCES}

1. Land WG. The role of postischemic reperfusion injury and other nonantigen-dependent inflammatory pathways in transplantation. Transplantation 2005;79:505-14. [CrossRef]

2. Behrend M. Immune-adhesion molecules in the prevention of allograft rejection and reperfusion injury. Expert Opin Investig Drugs 2000;9:789-805. [CrossRef]

3. Paterson IS, Klausner JM, Pugatch R, Allen P, Mannick JA, Shepro D, et al. Noncardiogenic pulmonary edema after abdominal aortic aneurysm surgery. Ann Surg 1989; 209:231-6. [CrossRef]

4. Welbourn CR, Goldman G, Paterson IS, Valeri CR, Shepro D, Hechtman HB. Pathophysiology of ischaemia reperfusion injury: central role of the neutrophil. Br J Surg 1991;78:651-5. [CrossRef]

5. Fantini GA, Conte MS. Pulmonary failure following lower torso ischemia: clinical evidence for a remote effect of reperfusion injury. Am Surg 1995;61:316-9.

6. Takhtfooladi MA, Jahanshahi A, Sotoudeh A, Jahanshahi G, Takhtfooladi HA, Aslani K. Effect of tramadol on lung injury induced by skeletal muscle ischemia-reperfusion: an experimental study. J Bras Pneumol 2013;39:434-9. [CrossRef]

7. Takhtfooladi H, Takhtfooladi M, Moayer F, Mobarakeh S. Melatonin attenuates lung injury in a hind limb ischemia-reperfusion rat model. Rev Port Pneumol 2015; 21:30-5. [CrossRef]

8. Takhtfooladi MA, Takhtfooladi HA, Sedaghatfar H, Shabani S. Effect of low-level laser therapy on lung injury induced by hindlimb ischemia/ reperfusion in rats. Lasers Med Sci 2015;30:1757-62. [CrossRef]

9. Calapai G, Marciano MC, Corica F, Allegra A, Parisi A, Frisina N, et al. Erythropoietin protects against brain ischemic injury by inhibition of nitric oxide formation. Eur J Pharmacol 2000;401:349-56. [CrossRef]

10. Gelgor L, Butkow N, Mitchell D. Effects of systemic non-steroidal anti-inflammatory drugs on nociception during tail ischaemia and on reperfusion hyperalgesia in rats. Br J Pharmacol 1992;105:412-6. [CrossRef]

11. Barthelemy S, Vergnes L, Moynier M, Guyot D, Labidalle S, Bahraoui E. Curcumin and curcumin derivatives inhibit Tat-mediated transactivation of type 1 human immunodeficiency virus long terminal repeat. Res Virol 1998;149:43-52. [CrossRef]

12. Shahed AR, Jones E, Shoskes D. Quercetin and curcumin up-regulate antioxidant gene expression in rat kidney after ureteral obstruction or ischemia/reperfusion injury. Transplant Proc 2001;33:2988. [CrossRef]

13. Yeh $\mathrm{CH}$, Chen TP, Wu YC, Lin YM, Jing Lin P. Inhibition of NFkap$\mathrm{paB}$ activation with curcumin attenuates plasma inflammatory cytokines surge and cardiomyocytic apoptosis following cardiac ischemia/reperfusion. J Surg Res 2005;125:109-16. [CrossRef]

14. Wang Q, Sun AY, Simonyi A, Jensen MD, Shelat PB, Rottinghaus GE, et al. Neuroprotective mechanisms of curcumin against cerebral ischemia-induced neuronal apoptosis and behavioral deficits. J Neurosci Res 2005;82:138-48. [CrossRef]

15. Thiyagarajan M, Sharma SS. Neuroprotective effect of curcumin in middle cerebral artery occlusion induced focal cerebral ischemia in rats. Life Sci 2004;74:969-85. [CrossRef]

16. Gaddipati JP, Sundar SV, Calemine J, Seth P, Sidhu GS, Maheshwari RK. Differential regulation of cytokines and transcription factors in liver by curcumin following hemorrhage/resuscitation. Shock 2003;19:150-6.

17. Yildirim Z, Kotuk M, Erdogan H, Iraz M, Yagmurca M, Kuku I, et al. Preventive effect of melatonin on bleomycin-induced lung fibrosis in rats. J Pineal Res 2006;40:27-33. [CrossRef]

18. Yagi K. Lipid peroxides and related radicals in clinical medicine. In: Armstrong D, editor. Free radicals in diagnostic medicine. New York: Plenum Press; 1994. p.1-15. [CrossRef]

19. Winterbourn CC, Hawkins RE, Brian M, Carrell RW. The estimation of red cell superoxide dismutase activity. J Lab Clin Med 1975;85:337-42.

20. Paglia DE, Valentine WN. Studies on the quantitative and qualitative characterization of erythrocyte glutathione peroxidase. J Lab Clin Med 1967;70:158-69.

21. Koksel O, Yildirim C, Cinel L, Tamer L, Ozdulger A, Bastürk M, et al. Inhibition of poly(ADP-ribose) polymerase attenuates lung tissue damage after hind limb ischemia-reperfusion in rats. Pharmacol Res 2005;51:453-62. [CrossRef]

22. Akbas H, Ozden M, Kanko M, Maral H, Bulbul S, Yavuz S, et al. Protective antioxidant effects of carvedilol in a rat model of ischaemia-reperfusion injury. J Int Med Res 2005;33:528-36. [CrossRef]

23. Kyriakides C, Austen WG Jr, Wang Y, Favuzza J, Moore FD Jr, Hechtman HB. Neutrophil mediated remote organ injury after lower torso ischemia and reperfusion is selectin and complement dependent. J Trauma 2000;48:32-8. [CrossRef]

24. Harkin DW, Barros D'sa AA, McCallion K, Hoper M, Halliday MI, Campbell FC. Circulating neutrophil priming and systemic inflammation in limb ischaemia-reperfusion injury. Int Angiol 2001;20:78-89.

25. Messent M, Griffiths MJD, Evans TW. Pulmonary vascular reactivity and ischaemia-reperfusion injury in the rat. Clin Sci (Lond) 1993;85:71-5.

26. Srivastava G, Mehta JL. Currying the heart: curcumin and cardioprotection. J Cardiovasc Pharmacol Ther 2009;14:22-7. [CrossRef]

27. Aggarwal BB, Harikumar KB. Potential therapeutic effects of curcumin, the anti-inflammatory agent, against neurodegenerative, cardiovascular, pulmonary, metabolic, autoimmune and neoplastic diseases. Int J Biochem Cell Biol 2009;41:40-59. [CrossRef] 
28. Avci G, Kadioglu H, Sehirli AO, Bozkurt S, Guclu O, Arslan E, et al. Curcumin protects against ischemia/reperfusion injury in rat skeletal muscle. J Surg Res 2012;172:39-46. [CrossRef]

29. Sak ME, Soydinc HE, Sak S, Evsen MS, Alabalik U, Akdemir F, et al. The protective effect of curcumin on ischemia-reperfusion injury in rat ovary. Int J Surg 2013;11:967-70. [CrossRef]

30. Sun J, Yang D, Li S, Xu Z, Wang X, Bai C. Effects of curcumin or dexamethasone on lung ischaemia-reperfusion injury in rats. Eur Respir J 2009;33:398-404. [CrossRef]

31. Nishino H, Tokuda H, Satomi Y, Masuda M, Osaka Y, Yogosawa S, et al. Cancer prevention by antioxidants. Biofactors 2004;22:57-61. [CrossRef]

32. Ghoneim AI, Abdel-Naim AB, Khalifa AE, El-Denshary ES. Protective effects of curcumin against ischaemia/reperfusion insult in rat forebrain.
Pharmacol Res 2002;46:273-9. [CrossRef]

33. Strasser EM, Wessner B, Manhart N, Roth E. The relationship between the anti-inflammatory effects of curcumin and cellular glutathione content in myelomonocytic cells. Biochem Pharmacol 2005;70:552-9.

34. Takhtfooladi MA, Asghari A, Takhtfooladi HA, Shabani S. The protective role of curcumin on testicular tissue after hindlimb ischemia reperfusion in rats. Int Urol Nephrol 2015;47:1605-10. [CrossRef]

35. Olguner C, Koca U, Kar A, Karci A, Işlekel H, Canyilmaz M, et al. Ischemic preconditioning attenuates the lipid peroxidation and remote lung injury in the rat model of unilateral lower limb ischemia reperfusion. Acta Anaesthesiol Scand 2006;50:150-5. [CrossRef]

36. Draper HH, Hadley M. Malondialdehyde determination as index of lipid peroxidation. Methods Enzymol 1990;86:421-31. [CrossRef]

\section{DENEYSEL ÇALIŞMA - ÖZET}

\section{Sıçanlarda akciğer hasarının oluşturduğu iskelet kası iskemi/reperfüzyonu üzerine zerdeçalın etkisi}

\section{Dr. Hamed Ashrafzadeh Takhtfooladi, ${ }^{1}$ Dr. Mohammad Ashrafzadeh Takhtfooladi ${ }^{2}$}

${ }^{1}$ İslam Azad Üniversitesi, Pathobiyoloji, Bilim ve Araştırma Bölümü, Tahran, İran

${ }^{2}$ İslam Azad Üniversitesi, Genç Araştırmacılar ve Seçkinler Kulübü, Bilim ve Araştırma Dalı, Tahran, İran

AMAÇ: Bu çalışma sıçanların arka bacakları bağlandıktan sonra oluşan akciğer hasarı üzerine zerdeçalın etkilerini araştırmak üzere yapıldı. GEREÇ VE YÖNTEM: Kırk adet Wistar sıçanı plasebo (GI), I/R (G2), zerdeçal + plasebo (G3) ve zerdeçal +i/R (G4) gruplarına ayrıldı. Çalışmadan önce iki hafta boyunca günde $200 \mathrm{mg} / \mathrm{kg}$ dozda zerdeçal verildi. Büyük trokanterlere iki saat boyunca turnike uygulandıktan sonra dört saat reperfüzyon için beklenerek $\mathrm{I} / \mathrm{R}$ oluşturuldu.

BULGULAR: Zerdeçalla öntedavi I/R grubuna göre akciğer dokularında malondialdehitlerin düzeyini anlamlı derecede düşürdü ve süperoksit dismütaz düzeyini yükseltti $(p<0.05)$. Gruplar arasında glutatyon peroksidaz aktivitesi açısından anlamlı farklılık yoktu $(p>0.05)$. I/R, enflamatuvar hücre infiltrasyonu ve alveoller içine kanama olmak üzere ciddi derecede histopatolojik hasara neden oldu $(p<0.05)$.

TARTIŞMA: Bu sonuçlar zerdeçalla öntedavinin kas I/R'nin neden olduğu akciğer hasarına karşı koruyucu etkileri olduğunu akla getirmektedir. Anahtar sözcükler: Akciğer; iskelet kası; iskemi/reperfüzyon; zerdeçal.

Ulus Travma Acil Cerrahi Derg 2019;25(I):7-II doi: 10.5505/tjtes.2018.83616 